\title{
The Analysis and Design of Electronic Student Worksheet Based on the Discovery Learning to Improve Critical Thinking Ability
}

\author{
Riana Julian", Suparman,", Irwan Djumat ${ }^{3}$, Bahran Taib ${ }^{4}$, Ermawati $^{5}$, Nurfitri Sahidun ${ }^{6}$, \\ Adityo Permana Wibowo ${ }^{7}$, Fadil Indra Sanjaya ${ }^{7}$, Sulistyo Dwi Sancoko ${ }^{7}$ \\ ${ }^{1,2}$ Postgraduate Program in Mathematics Education, Faculty of Teacher Training and Education, Universitas Ahmad Dahlan, \\ Yogyakarta, Indonesia \\ ${ }^{3,4}$ Faculty of Teacher Training and Education, Universitas Khairun, Ternate, Indonesia \\ ${ }^{5}$ Faculty of Economics and Islamic Business, Institut Agama Islam Negeri Palu, Palu, Indonesia \\ ${ }^{6}$ Faculty of Tarbiyah and Teacher Training, Institut Agama Islam Negeri Ternate, Ternate, Indonesia \\ ${ }^{7}$ Faculty of Information Technology and Electrical Engineering, Universitas Teknologi Yogyakarta, Yogyakarta, Indonesia
}

Received September 5, 2020; Revised November 18, 2020; Accepted December 13, 2020

\section{Cite This Paper in the following Citation Styles}

(a): [1] Riana Julian, Suparman, Irwan Djumat, Bahran Taib, Ermawati, Nurfitri Sahidun, Adityo Permana Wibowo, Fadil Indra Sanjaya, Sulistyo Dwi Sancoko, "The Analysis and Design of Electronic Student Worksheet Based on the Discovery Learning to Improve Critical Thinking Ability," Universal Journal of Educational Research, Vol. 8, No. 12B, pp. 8022-8033, 2020. DOI: 10.13189/ujer.2020.082603.

(b): Riana Julian1, Suparman, Irwan Djumat, Bahran Taib, Ermawati, Nurfitri Sahidun, Adityo Permana Wibowo, Fadil Indra Sanjaya, Sulistyo Dwi Sancoko (2020). The Analysis and Design of Electronic Student Worksheet Based on the Discovery Learning to Improve Critical Thinking Ability. Universal Journal of Educational Research, 8(12B), 8022-8033. DOI: 10.13189/ujer.2020.082603.

Copyright $(2020$ by authors, all rights reserved. Authors agree that this article remains permanently open access under the terms of the Creative Commons Attribution License 4.0 International License

\begin{abstract}
Critical thinking is one of the abilities that need to be given to students in $21^{\text {st }}$ century learning. If students do not have critical thinking ability, students will experience obstacles in achieving learning goals. Learning resources could facilitate students in enhancing critical thinking ability. This research aims to analyze and design electronic student worksheet material based on discovery learning model to enhance critical thinking ability. Electronic student worksheets are developed with the ADDIE model. The subject of this research is $8^{\text {th }}$-grade students of Muhammadiyah 1 Pundong Junior High School. The instruments used were validation sheets, an observation guide, and an interview guide. The validation sheets were given to the material and media experts to assess the electronic student worksheet quality. Interviews were conducted towards teachers and students to gain information about the curriculum and students' characteristics. The data were analyzed through data reduction, data presentation, and conclusions were drawn. The result of this research shows that electronic student worksheet needs to be developed with regard to the
\end{abstract}

discovery learning model and students' characteristics. The electronic student worksheet is designed to enhance critical thinking ability. Further research could be conducted towards the development stages, implementation, and evaluation. The results of this study can be used as a guide for mathematics teachers in developing electronic student worksheet that makes students understand mathematics and have critical thinking skills simultaneously. The novelty of this research is to integrate critical thinking skills into electronic student worksheet. In addition, electronic student worksheet is designed according to the discovery learning model.

Keywords Electronic Student Worksheet, Discovery Learning, Critical Thinking

\section{Introduction}

Students need to have Critical thinking ability in the 
industry 4.0 era. The ability to think critically in the $21^{\text {st }}$-century is really important since it's related to social, scientific, and functional [1]. Critical thinking ability is an organized mental process that plays a role in the decision-making process to solve problems, including analyzing activities and data in scientific investigation activities. To determine whether a student is considered as a good or low critical thinker, we can find out from the ability of students to interpret problems, analyze problems, evaluate problems, conclude problems, can explain what they think, make a decision, use the power of critical themselves for themselves, and can make a right decision [2]. Therefore, critical thinking is important to be given when the teachers are explaining in class so that students' knowledge and learning abilities increase [3]. Aside from that, critical thinking is an important ability in life to choose learning strategies in class [4]. From the explanation above, it can be concluded that each student should have critical thinking ability.

Mathematical critical ability is a basic mathematical competency that is important at the level of the mathematics education curriculum unit in Indonesia. Mathematical critical thinking ability is not only important to meet the demands of learning mathematics but also to know students' awareness that mathematics is important in other subjects and everyday life [5]. Critical thinking in mathematics is a thinking test, to question, to connect, and to evaluate every aspect of situations or mathematical problems [6]. Mathematics is one of the subjects that must be mastered by students. The purpose of learning mathematics is to train the ability to think logically, analyze systematically and critically, innovate, be creative, and be able to work together [7]. Some research explains that effective learning strategies are needed to create a well-organized mathematics learning process [8-10].

Students can deepen the understanding of mathematical concepts through carefully selected problems using mathematical applications for real problems. Ability development to solve mathematical problems can make students think critically, logically, creatively, analytically, and systematically [11]. The ability to think critically is a form of reason in which a person can increase the potential to think through the process of analysis and evaluation of problems [12]. Therefore, critical thinking ability encourages students to think independently in solving problems in school or in the context of everyday life. Critical thinking ability is a priority in educational goals [13].

Mathematics is one of the subjects that can develop critical thinking ability. In the context of mathematics, critical thinking encourages teachers and students to learn more about the definitions that appear from mathematical concepts [14]. Therefore, students can be more active in class and could complete a given problem. Based on a conducted observation of previous studies, students' critical thinking ability is not optimal. One of the reasons is the learning models used by teachers are still unable to stimulate critical thinking ability. One of the causes of low levels of critical thinking ability is the implementation of teacher-centered teaching. Students as recipients of science education are still passive in accepting learning [15]. Teachers must create a more active learning atmosphere and involve activities where students find their knowledge. According to Balim (2009: 2) teachers can carry out learning activities in class using discovery learning methods to make students active in finding, critical thinking, questioning, and problem-solving skills [16]. Through the discovery learning method, students can explore and create their understanding through the process of problem-solving or investigation. In problem-solving, students can take over their learning process while building new knowledge based on previous learning. This discovery process includes the development of many abilities in the form of critical abilities, observation, reasoning, measurement of numerical data manipulation, preparation of schedules, graphs, and interpretation of data [17]. In the discovery learning method, students are directed to build and create relations between the knowledge they have and everyday life [18]. The steps in the discovery learning method are as follows: (1) stimulation, (2) statement/ problem identification, (3) data collection, (4) data processing, (5) verification, (6) drawing conclusion/generalization [19].

One other solution needed to improve $21^{\text {st }}$-century skills is to develop teaching materials that can facilitate student learning activities. So learning can form active interactions between students and teachers [10]. The use of teaching materials allows students to understand these materials in a shorter and more enjoyable time [20]. One of the teaching materials that can be developed by teachers is an electronic student worksheet, while a learning medium that could help teachers in the learning process is a student worksheet. Student worksheet could help students in understanding and learning materials independently and responsibly. The student worksheet is the most effective and simplest medium in learning [21]. On the other hand, researchers conducted an observation on student worksheets that are used at schools. The obtained score is $65.71 \%$. Several things that were found from the assessment towards the student worksheet which are (1) the student worksheet does not encourage students to ask questions, (2) the appearance of the student worksheet is not following the materials, (3) student worksheet does not display illustrations or pictures that clarify the problem, (4) the pictures and illustrations are not interesting, (5) it's not easy for students to understand the materials in the student worksheet, (6) there are unsolved problems, (7) student worksheet is not a learning model [22].

The purpose of this study is to analyze and design teaching materials in the form of electronic student 
worksheets based on discovery learning method to improve critical thinking ability.

\section{Methodology}

This research uses development research. The development procedure of electronic student worksheets uses the ADDIE model. ADDIE model includes five steps as follows: analysis, design, implementation, development, and evaluation [23]. ADDIE model is the most popular learning model design since it has steps that are adjusted in detail [24].

The ADDIE model development can be visually seen in Figure 1 as follows:

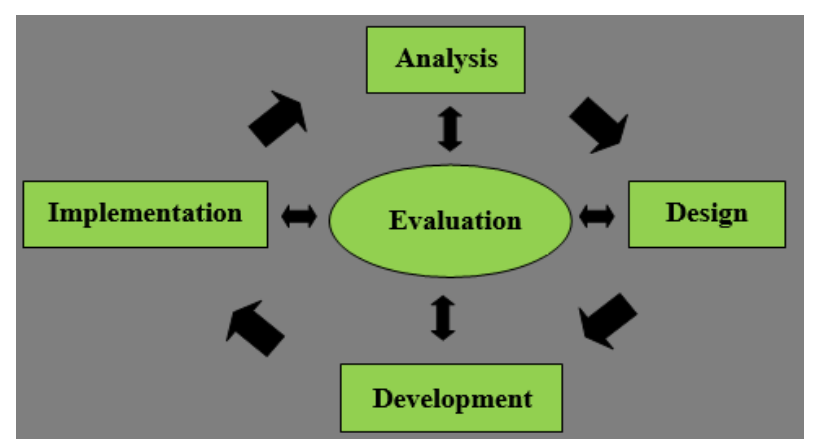

Figure 1. ADDIE Model

This research is only limited to two steps, which are analysis and design. The analysis step that was conducted in this study is divided into three which are curriculum analysis, material analysis, and students' characteristics analysis. The result of these analyses was used as the basis to develop a product in the form of an electronic student worksheet based on discovery learning model to enhance critical thinking ability. The design step that was conducted in this research started with a product framework, learning strategies, and designing a product prototype.

The data collection techniques in this research used observations and interviews. The observations and interviews were conducted to find out the curriculum used, student characteristics, and student needs. The type of data that is generated from this research is qualitative data in the form of students' characteristics, information on the use of curriculum in schools, and advice from media and material experts. While the quantitative data were obtained in a form of scores from the accurate assessment results from media and material experts. The data analysis technique in this research used data reduction, data presentation, and conclusion.

\section{Result and Discussion}

This research resulted in the need analysis related to electronic student worksheets and the design of electronic student worksheets based on the discovery learning model that could enhance the critical thinking ability.

\subsection{Analysis Step}

\subsubsection{Curriculum Analysis}

Researchers conducted interviews and observations on $8^{\text {th }}$-grade mathematics teachers. Researchers gained information that the used curriculum is a revised 2013 curriculum. The learning resources are in accordance with the standards of competency, core competencies, and basic competencies according to the curriculum.

\subsubsection{Material Analysis}

Students find it difficult in understanding the equation of straight lines learning materials. Students have difficulty in determining the equation of the line if the graphic images are known. Students also find it difficult to apply straight-line equations in everyday life. Students will need a little time to complete the problem when they are given practice questions that are different from the examples given before.

\subsubsection{Students' Characteristic Analysis}

Researchers conducted interviews with students. Researchers found out that some students cannot absorb mathematics learning well. Students need electronic student worksheet that is easier to be studied and is fun for the students. Teachers have difficulties in the mathematics learning process because of the learning media. A learning medium that makes learning more effective is needed so that students can be good at the mastery of concepts and understanding.

\subsection{Design Step}

The next step is to design. In this step, an electronic student worksheet based on discovery learning model was designed to enhance the critical thinking ability of 8th-grade junior high school students. The parts of the electronic student worksheet that has been designed include cover, preface, basic competencies, core competencies, indicator, the achievement of competence, instructions for use, concept map, material, and exercises. The researchers collected student worksheets based on the steps of the discovery learning method. The following are some of the designs that have been made by researchers.

\subsubsection{Cover}

The cover page consists of title with the discovery learning approach with critical thinking ability, 2013 curriculum logo, material title, target user, author's name, logo, and institution logo. The cover can be seen in Figure 2. 


\section{Riana Julian}

\section{MATEMATIKA}

Lembar Kerja Peserta Didik

Persamaan Garis Lurus

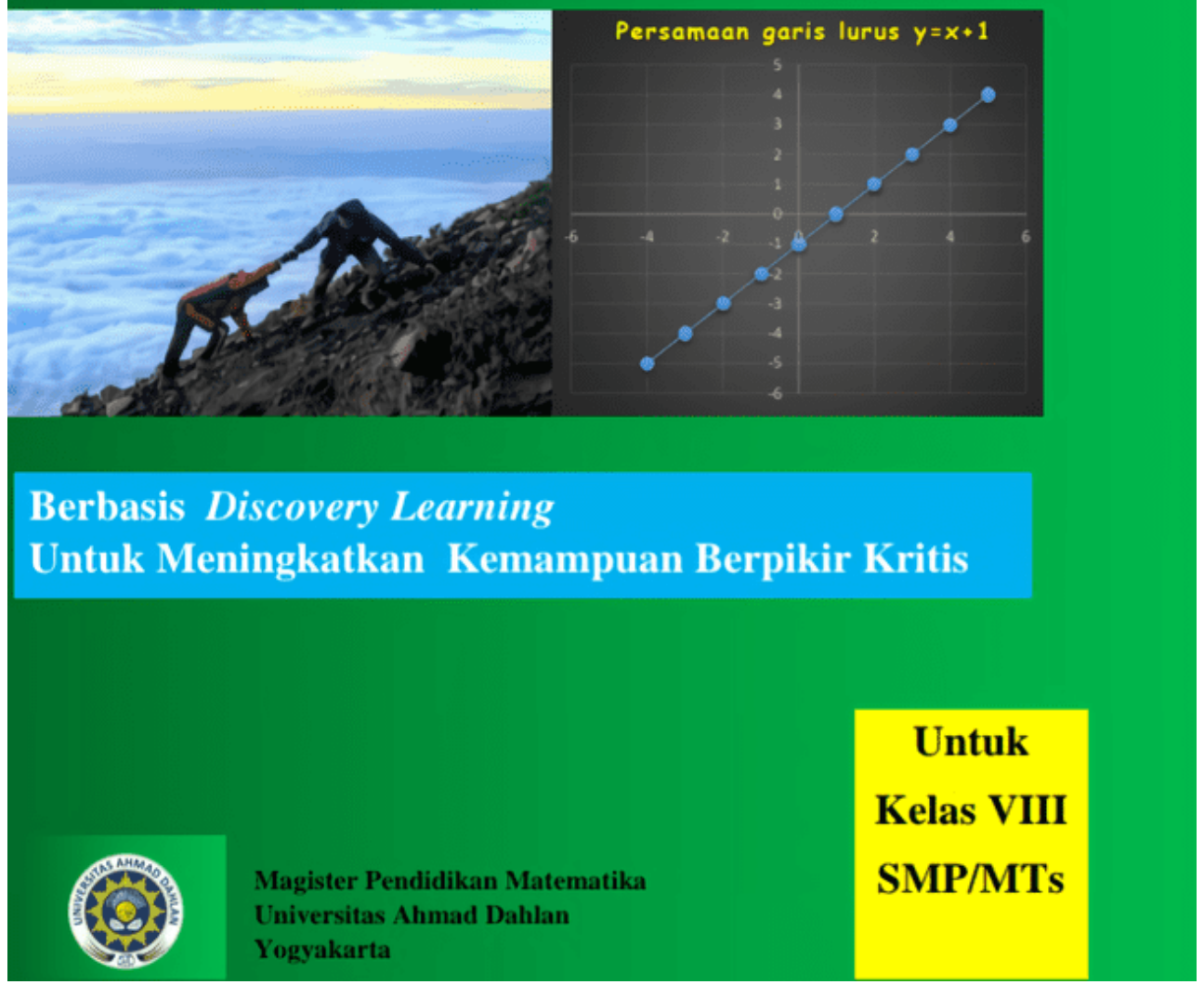

Figure 2. Showing electronic student worksheet cover 


\subsubsection{Preface}

The preface contains the gratitude of the author to those who have helped in the preparation and design of this product Preface can be seen in Figure 3.

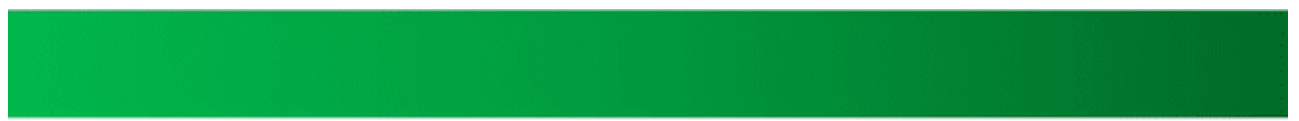

\section{Kata Pengantar}

Segala puji dan syukur kehadirat Allah yang maha kuasa, karena rahmat dan hidayahNya penulisan Elektronik Lembar Kerja Peserta Didik (E-LKPD) matematika ini dapat diselesaikan. ELKPD ini disusun sebagai salah satu sumber bahan ajar yang dapat digunakan dalam kegiatan belajar di sekolah.

Penulis sampaikan banyak terima kasih kepada semua pihak yang telah membantu dan membimbing dalam penyelesaian E-LKPD ini. E-LKPD berisikan materi pembelajaran Persamaan Garis Lurus berbasis Discovery Learning untuk siswa kelas VIII, disusun dengan harapan dapat memfasilitasisiswa dalam pemahaman konsep dan dapat meningkatkan kemampuan berpikir kritis siswa.

Penulis menyadari dalam penyusunan E-LKPD ini masih jauh dari sempurna. Oleh karena itu, kritik dan saran pembaca senantiasa penulis harapkan. Atas perhatian dan kerjasamanya diucapkan terima kasih

Yogyakarta, April 2020

Figure 3. Shows preface 


\subsubsection{Core Competencies, Basic Competencies, and Indicators of Competency Achievement}

This page describes core competencies, basic competencies, and indicators of competency achievements as the goals in learning the equation of straight lines learning material. Basic competencies, core competencies, and the indicators of competency achievement can be seen in Figure 4.

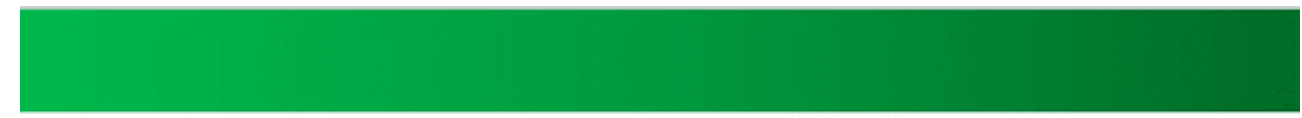

\section{Standar Isi Kurikulum 2013}

\section{KI}

1. Menghargai dan menghayati ajaran agama yang dianutnya.

2. Menghargai dan menghayati perilaku jujur, disiplin, tanggung jawab, peduli (gotong-royong, toleransi), santun, percaya diri, dalam berinteraksi secara efektif dengan lingkungan sosial dan alam dalam jangkauan pergaulan dan keberadaannya.

3. Memahami pengetahuan (faktual, konseptual, dan prosedural) berdasarkan rasa ingin tahunya tentang ilmu pengetahuan, teknologi, seni, budaya terkait fenomena dan kejadian tampak mata.

4. Mengolah, menyajikan, dan menalar dalam ranah konkret (menggunakan, mengurai, merangkai, memodifikasi, dan membuat) dan ranah abstrak (menulis, membaca, menghitung, menggambar, dan mengarang) sesuai dengan yang dipelajari di sekolah dan sumber lain yang sama dalam sudut pandang/teori.

\section{KD}

3.4 Menganalisis fungsi linear (sebagai persamaan garis lurus) dan Menginterfretasikan grafiknya yang dihubungkan dengan masalah kontekstual.

4.4 Menyelesaikan masalah konteksual yang berkaian dengan linear sebagai persamaan garis lurus.

\section{IPK}

* Menyebutkan persamaan garis dalam berbagai bentuk dan variabel.

* Menentukan gradien garis lurus dalam berbagai bentuk logis dan kritis.

* Menemukan persaman garis lurus jika diketahui gambar garisnya.

* Menentukan persamaan garis lurus melalui satu titik dan gradien.

* Menentukan persamaan garis lurus yang melalui dua titik.

* Menyelesaikan masalah kontekstual yang berkaitan dengan persamaan garis lurus.

* Menyelesaikan masalah kontekstual yang berkaitan dengan membuat persaman garis melalui satu titik dan gradient, serta dua titik.

* Menyelesaikan masalah kontekstual yang berkaitan dengan persamaan garis yang sejajar dengan garis lain. serta garis yang tegak lurus dengan garis lain

Figure 4. Shows core competencies, basic competencies, and indicators of competency achievement 


\subsubsection{Concept Map}

Concept map in electronic student worksheet based on discovery learning method contains topics that must be studied. This concept map also helps teachers to improve the effectiveness of the learning process in the classroom. Figure 5 shows the concept of map design.

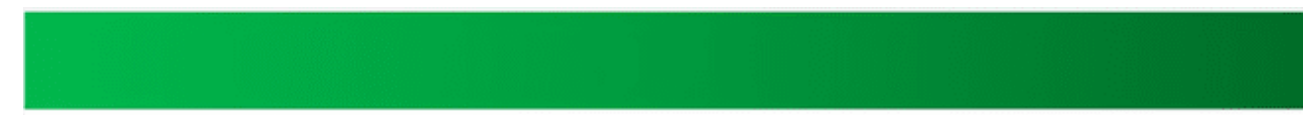

\section{Peta Konsep}

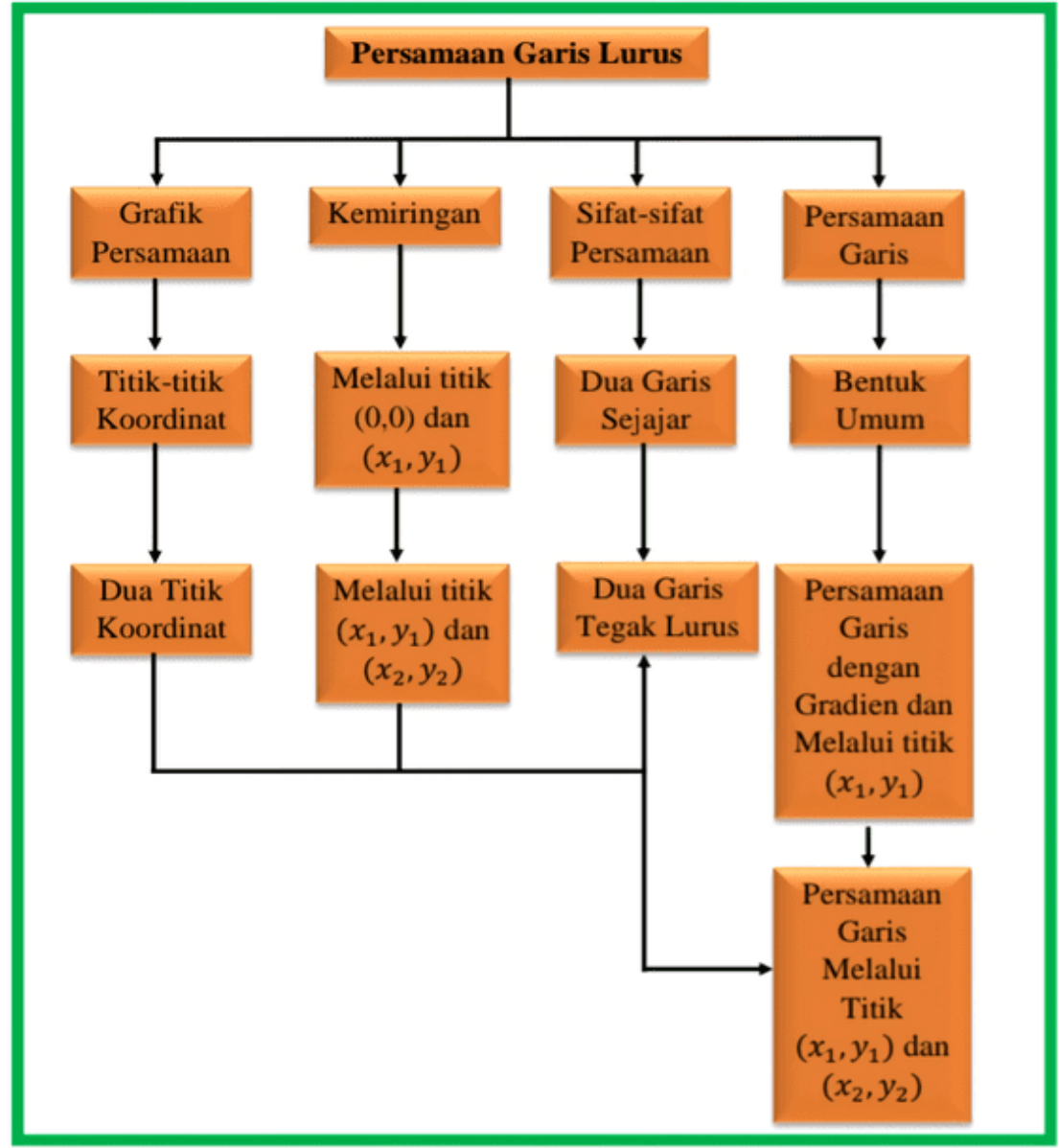

Figure 5. Shows Concept Map Design 


\subsubsection{Instructions for Use}

The instruction for use of electronic student worksheets contains the process of students in solving exercises with the steps that are available in the discovery learning method. Figure 6 shows the design of instructions for use.

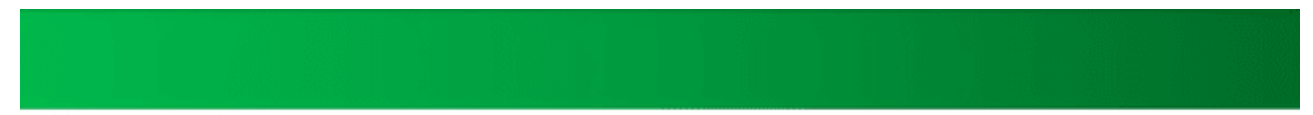

\section{Petunjuk Penggunaan E-LKPD}

Materi dan soal-soal latihan yang disajikan dalam E-LKPD ini, akan mengikuti serangkaian kegiatan berdasarkan langkah-langkah model pembelajaran Discovery Learning yang bertujuan memberi pengalaman belajar siswa dalam memahami materi Persamaan Garis Lurus, langkah-langkah tersebut diantaranya sebagai berikut:

a. Stimulation (stimulasi/pemberian rangsangan) Menyediakan kondisi interaksi belajar yang dapat mengembangkan dan membantu peserta didik dalam mengeksplorasi bahan.

b. Problem statement (pernyataan/ identifikasi masalah) Peserta didik mengidentifikasi sebanyak mungkin agenda-agenda masalah yang relevan dengan bahan pelajaran, kemudian salah satunya dipilih dan dirumuskan dalam bentuk hipotesis

c. Data collection (Pengumpulan Data)

Peserta didik mengumpulkan informasi sebanyak-banyaknya yang relevan untuk membuktikan benar atau tidaknya hipotesis

d. Data Processing (Pengolahan Data)

Peserta didik mengolah data dan informasi yang telah diperoleh melalui wawancara, observasi, dan sebagainya, lalu ditafsirkan

e. Verification (Pembuktian)

Peserta didik menemukan suatu konsep, teori, aturan atau pemahaman melalui contoh-contoh yang ia jumpai dalam kehidupannya.

f. Generalization (menarik kesimpulan/generalisasi) Peserta didik menarik sebuah kesimpulan yang dapat dijadikan prinsip umum dan berlaku untuk semua kejadian atau masalah yang

Figure 6. Shows Instructions for Use 


\subsubsection{Material}

The material page contains a brief summary of straight-line equations material. The summary helps students to have an initial view of the material they are going to learn. Figure 7 shows a summary of the straight-line equation materials.

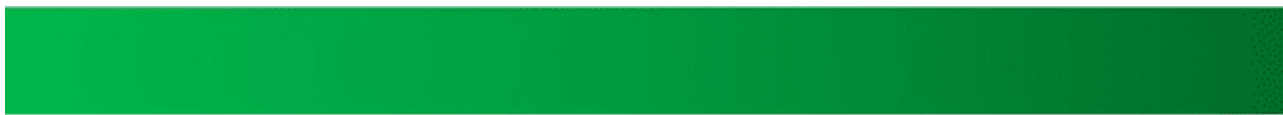

\section{Ringkasan Materi}

\section{Gradien Garis}

- Gradient dari ruas garis melalui dua titik $A\left(x_{1} y_{1}\right)$ dan $B\left(x_{2} y_{2}\right)$ ditulis $m_{A B}$

Rumus $m_{A B}=\frac{y_{z}-y_{2}}{x_{2}-x_{2}}$

- Gradient pada persamaan garis:

1. Bentuk eksplisit $y=m x+c \Rightarrow$ gradient $=m$ (koefisien $\mathbf{x}$ )

2. Bentuk Implisit $a x+b y+c=0 \Rightarrow$ gradient $=-\frac{a}{b}$

Membuat Persamaan Garis Lurus

- Diketahui gradient $m$ dan melalui titik $\left(x_{1}, y_{2}\right)$

Rumus: $y-y_{1}=m\left(x-x_{1}\right)$

- Diketahui garis melalui dua titik $\left(x_{1}, y_{1}\right)$ dan $\left(x_{2} y_{2}\right)$ Rumus: $\frac{y-y_{1}}{y_{2}-y_{1}}=\frac{x-x_{1}}{x_{2}-x_{1}}$

Sifat Garis $y=m x+c$

- Garis memiliki gradient $m$ jika $m>0$ (positif) maka garis condong kekanan (naik) sedangakan jika $m<0$ (negatif) maka garis condong kekiri (turun).

- Garis tersebut memotong sumbu $Y$ di titik $(0, c)$.

- Jika $c>0$ maka garis memotong sumbu $Y$ diatas sumbu $X$. sedangkan jika $c<0$ maka garis memotong sumbu $Y$ di bawah sumbu $X$.

Hubungan Dua Garis

Misalkan ada dua garis, masing-masing garis $g_{1}$ dengan persamaan $y=m_{1} x+c_{1}$ dan garis $g_{2}$ dengan persamaan $y=m_{2} x+c_{2}$. Hubungan keduanya dapat ditentukan oleh gradiennya.

Jika dua garis g sejajar maka : $m_{1}=m_{2}$

Jika dua garis g saling tegak lurus maka: $m_{1} \times m_{2}=-1$

Figure 7. Shows summary of the material 

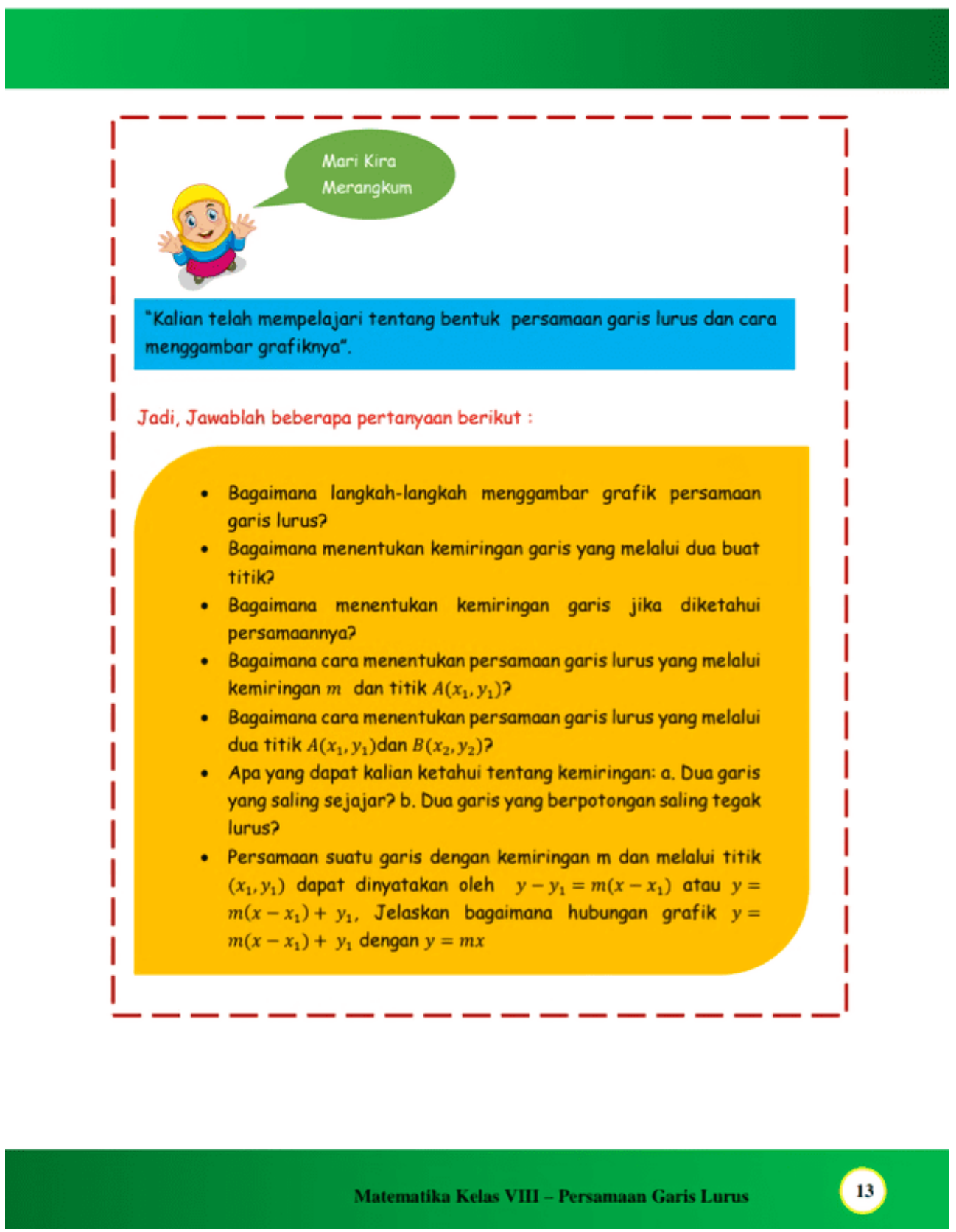

Figure 8. Shows Exercise

\subsubsection{Exercise}

The exercises in this electronic learning worksheet based on discovery learning method contain problems that must be solved by students. The purpose of preparing these exercises is to educate students so they can think critically in solving problems. Aside from that, these exercises are prepared so that students can understand the straight-line equation material that has been learned. Figure 8 shows an example of one of the exercises contained in the electronic student worksheet.

The developed product design was assessed by the validators. The following was a validation procedure for students' worksheet designs. First, the validators made validation guidelines based on indicators. Second, the validators evaluated the students' sheet designs using validation guidelines. Third, the design of the student sheets was corrected according to the comments of the validators. Fourth, the validators verified whether the student sheet design has been revised in accordance with the comments.

The assessment was done by validating the product, where there were expert and media validation. In the expert validation step, the assessment was conducted to determine the validity of the electronic student worksheet design. The electronic student worksheet that has been approved by the supervisor then was validated by the validator, lecturers, and expert of material and media. The validation of the electronic student worksheet used the 
scoring instrument that has been reviewed by the validator. Several advice and suggestions from the material expert were summarized in the table as follows.

Table 1. Advice and Suggestions from Expert

\begin{tabular}{ccc}
\hline No & Suggestions and Comment & Follow Up \\
\hline 1. & To add the indicator of critical thinking & Has been added \\
2. & To give evaluation problems at the end & Has been added \\
3. & of learning & Has been added \\
4. & To add more materials & Has been added \\
\hline
\end{tabular}

The researchers have revised the product based on the advice and suggestions from experts. Aside from that, the feasibility of the learning material was also assessed by two material experts. The results of experts' questionnaire calculations on the feasibility of instructional media design are presented as follows in table 2 .

Table 2. The Results of Questionnaire Calculations on the Feasibility

\begin{tabular}{cccc}
\hline $\begin{array}{c}\mathrm{N} \\
\mathrm{o}\end{array}$ & Evaluator & Position & $\begin{array}{c}\text { The Criteria for } \\
\text { Quantitative Data }\end{array}$ \\
\hline 1. & $\begin{array}{c}\text { Aisyah Nur } \\
\text { Istiqomah }\end{array}$ & $\begin{array}{c}\text { Mathematics } \\
\text { Teacher } \\
\text { Mathematics } \\
\text { Teacher }\end{array}$ & Very Good \\
2. & Susanti & Very Good \\
\hline
\end{tabular}

Based on table 2, it can be seen that the average value of the product results shows that the developed design of the electronic student worksheet learning media is in a very good category.

The research can be continued to the development, implementation, and evaluation steps. In the development step, researchers can gather data sources, develop learning materials, and validate product design. The implementation step is the application of the product that has been made for trials in small groups of students. A trial is conducted to see the effect of the product on learning. The fifth step is evaluation. An evaluation is carried out to assess the overall product that has been made and applied [25].

\section{Conclusion}

This research has resulted in a needs analysis and design of electronic student worksheets based on model discovery learning to improve critical thinking skills.

The researchers grouped the analysis step into three which are: curriculum analysis, material analysis, and students' characteristic analysis. The used curriculum was the 2013 curriculum. In the material analysis, students have difficulty in straight line equation material. Regarding the characteristics of students, researchers found that students tend to be passive. Students need a medium that can help them understand the provided mathematical material. In the design step, the researcher has designed the initial worksheet. The design included a preface, basic competencies, core competencies, indicator of competence achievement, instructions for use, map concept, material, and exercises. The development of students' understanding is found in problem-solving and evaluation training. The developed electronic student worksheet has the advantage that it can build student understanding and improve students' critical thinking ability on the subject matter of straight-line equations. This is because each indicator of critical thinking ability appears on questions in the electronic student worksheet. The electronic student worksheet also integrates the discovery learning model.

This research has limited it to two stages, namely: analysis and design. This research can be developed at the development, implementation, and evaluation steps to determine the feasibility and the effectiveness of the worksheets in the learning process.

The results of this study can be used as a guide for teachers in developing electronic student worksheets when the teacher uses the discovery learning model so that students not only understand the material but also students' critical thinking abilities can also be developed.

\section{Acknowledgements}

The researchers would like to say thank you to the Postgraduate Program in Mathematics Education, Universitas Ahmad Dahlan (Indonesia) who always provide guidance and facilities in completing this research. The researchers would also like to say thank you to Universitas Khairun (Indonesia), IAIN Palu (Indonesia), IAIN Ternate (Indonesia), Universitas Teknologi Yogyakarta (Indonesia), and SMP Muhammadiyah 1 Pundong, Yogyakarta (Indonesia) who have helped and provided support in this research.

\section{REFERENCES}

[1] Abbasi, A. and Izadpanah, S., "The Relationship between Critical Thinking, Its Subscales and Academic Achievement of English Language Course: The Predictability of Educational Success Based on Critical Thinking," Academy Journal of Educational Sciences, vol. 2, no. 2, pp. 91-105, 2018.

[2] [2] Rasiman, "Leveling of Critical Thinking Abilities of Student of Mathematics Education Mathematical Problem Solving," Journal on Mathematics Education," vol.6, no.1, pp. 40-52, 2015.

[3] [3] Kristensson, M., "Critical Thinking in the Classroom, C-essay," Hogskolan I Halmstad: Sektionen for lararutbildning, pp. 61-90, 2013.

[4] [4] Gupta, S., and Ahmad, I., "Strategies to Promote Critical Thinking in Learners," International Journal Researcher's 
Guild Articles, vol.1, no.1, 2018.

[5] [5] Widyaningtyas, R., Kusumah, Y.S., Sumarno, U., and Sabandar, J., "The Impact of Problem-Based Learning Approach to Senior High School Students' Mathematics Critical Thinking Ability," Journal on Mathematics Education, vol.6, no.2, pp. 30-38,2015.

[6] [6] Palinussa, A.L., "Students' Critical Mathematical Thinking Skills and Character: Experiments for Junior High School Students through Realistic Mathematics Education Culture-Based," Journal on Mathematics Education, vol.4, no.1, pp. 75-94, 2013.

[7] Triyono, A., and Suparman, "Inquiry-Based Worksheet Design to Improve Critical Thinking of Students in Indonesial, International Journal of Scientific \& Technology Research," vol.8, issue 10, pp. 1183 - 1187, 2019.

[8] Sulistyaningsih, A., Suparman, and Rakhmawati, E., "Mathematics Module Development Design Based on PBL to Improve Mathematics Problem-Solving Ability," International Journal of Scientific \& Technology Research, vol.8, issue 11, pp. 2508-2516, 2019.

[9] Syafina, B.P., and Suparman, "Designing Student Worksheets to Improve Critical Thinking Ability Based on Problem Based Learning, International Journal of Scientific \& Technology Research," vol.8, issue 10, pp. 1194-1199, 2019.

[10] Solihati, S., and Suparman, "Design of Mathematics Module Development Based on PMRI to Improve Critical Thinking Ability Students of Class Viii Junior High School In Indonesia," International Journal of Scientific \& Technology Research, vol.8, issue 10, pp. 3373-3379, 2019.

[11] Surya, E., Putri, F.A., and Mukhtar, "Improving Mathematical Problem-Solving Ability and Self-Confidence of High School Students through Contextual Learning Model," Journal on Mathematics Education, vol.8, no.1, pp. 85-94, 2017.

[12] Aksu, G., and Koruklu, N., "Determination the Effects of Vocational High School Students' Logical and Critical Thinking Skills on Mathematics Success," Eurasian Journal of Educational Research, issue 59, pp. 181-206, 2015.

[13] Utami, B., Saputro, S., Masykuri, M., and Widoretno, S., "Critical Thinking Skills Profile of High School Students in Learning Chemistry," International Journal of Science and Applied Science: Conference Series. vol.1, no.2, pp. 124-130, 2017.

[14] Kusumaningrum, H., and Suparman, "Design of Social Arithmetic Students Worksheets with RME Approaches to
Improve Critical Thinking Ability," International Journal of Scientific \& Technology Research., vol.9, issue 3, pp. 4978-4982, 2020.

[15] Badengo, T., and Suparman, "Design Module of Learning with RME Approach to Improve Creative Thinking Ability, International Journal of Scientific \& Technology Research," vol.8, issue 10, pp. $1178-1182,2019$.

[16] Arianto, M.A., and Sari, S.Y., "Discovery Learning in Lesson Study," Advances in Social Science, Education and Humanities Research, vol. 276, pp. 81-84, 2019.

[17] Siregar, N.C., Rosli, R., and Maat, S.M., "Development of the D-Geometry Module Based on Discovery Learning," International Journal of Academic Research in Progressive Education and Development, vol.8, no.3, 99-109, 2019.

[18] Pursitasari, I.D., Suhardi, E., and Sunarti, T., "Promoting Science Literacy with Discovery Learning," IOP Conf. Series: Journal of Physics: Conf. Series, vol. 1233, 1-5, 2019.

[19] Syara, R., Setia, U.C., and Rolina, R., "Enhance Mathematical Understanding by Discovery Learning," Journal of Learning Mathematics Learning, vol.1, no.3, pp. 318-321, 2018.

[20] Salampessy, Y.M., and Suparman, "Design of Probability Module Based on PBL Learning Model to Improve Critical Thinking Skills," International Journal of Scientific \& Technology Research, vol.9, issue 3, pp. 5695-5701, 2020.

[21] Asrori, A., and Suparman, "Design of Probability E-LKPD According to Problem Based Learning Model to Enhance Creative Thinking Skills," International Journal of Scientific \& Technology Research, vol.9, issue 3, pp. 3970-3976, 2020.

[22] Sayekti, A.M., and Suparman, "Development of PJBL-Based LKPD with STEM Approach Design to Improve Critical Thinking Skills," International Journal of Scientific \& Technology Research, vol.9, issue 3, pp. 3390-3394, 2020.

[23] Mujahidah, F.W., and Suparman, "Student's Worksheets Design for Eighth Grade to Improve Problem-Solving Ability with RME," International Journal of Scientific \& Technology Research, vol.8, issue 11, pp. 3912-3917, 2019.

[24] Durak, G., and Ataizi, M., "The ABC's of Online Course Design According to ADDIE Model," Universal Journal of Educational Research, vol. 4, no. 9, pp. 2084-2091, 2016.

[25] Widyastuti, E., and Susiana, "Using the ADDIE model to Develop Learning Material for Actuarial Mathematics," IOP conf. Series: Journal of physics: conf. series, vol. 1188, pp. $1-8,2019$. 